\title{
Archeological Tourist Destination Image Formation: Influence of Information Sources on the Cognitive, Affective and Unique Image
}

\author{
Nuria Huete-Alcocer ${ }^{*}$, Maria Pilar Martinez-Ruiz²*, Víctor Raúl López-Ruiz ${ }^{1 *}$ and \\ Alicia Izquiedo-Yusta ${ }^{3 *}$
}

1 Department of Spanish and International Economics, Econometrics, History and Economic Institutions, University of Castilla-La Mancha, Ciudad Real, Spain, ${ }^{2}$ Department of Economy and Business Administration, University of Castilla-La Mancha, Ciudad Real, Spain, ${ }^{3}$ Department of Economy and Business Administration, University of Burgos, Burgos, Spain

\section{OPEN ACCESS}

Edited by:

Giulio Arcangeli,

University of Florence, Italy

Reviewed by:

Luigi Isaia Lecca,

University of Cagliari, Italy

Jorge Pelegrín-Borondo,

University of La Rioja, Spain

${ }^{*}$ Correspondence:

Nuria Huete-Alcocer Nuria.Huete@uclm.es

Maria Pilar Martinez-Ruiz MariaPilar.Martinez@uclm.es Víctor Raúl López-Ruiz Victor.lopez@uclm.es Alicia Izquiedo-Yusta aliciaiz@ubu.es

Specialty section: This article was submitted to Organizational Psychology, a section of the journal Frontiers in Psychology

Received: 12 July 2019 Accepted: 07 October 2019 Published: 22 October 2019

Citation: Huete-Alcocer N, Martinez-Ruiz MP, López-Ruiz VR and Izquiedo-Yusta A (2019) Archeological Tourist Destination Image Formation: Influence of Information Sources on the Cognitive, Affective and Unique Image. Front. Psychol. 10:2382. doi: 10.3389/fpsyg.2019.02382
A destination's image is a critical factor in tourists' perceptions and evaluations of said destination. This paper analyzes the formation of the tourist destination image of Segóbriga Archeological Park, a cultural destination located in the province of Cuenca (Spain) that holds great heritage value. To this end, the paper adopted a multidimensional approach and used PLS-SEM to analyze the destination image, taking into account not only its cognitive and affective components, but also the unique image component. The latter has received less attention in the literature and is a novel factor among cultural destinations. The results show that this component is essential to the overall image of an archeological destination, but is not influenced by information sources.

Keywords: information sources, tourism destination image, cognitive image, affective image, unique image

\section{INTRODUCTION}

With international tourism on the rise, destinations are locked in an increasingly intense competition for people's attention. In order to survive in today's global market, it is necessary for destinations to offer and manage a positive, yet differentiated image (Qu et al., 2011). Indeed, destination image is a fundamental factor in travelers' selection of and behavior toward a destination (Gunn, 1972; Gartner, 1994; Bigné et al., 2001; Millet, 2010; Carballo et al., 2015; Elliot and Papadopoulos, 2016). This image is a mental concept formed from a set of impressions drawn from numerous information sources (Beerli and Martín, 2004); it is traditionally delineated into the cognitive and affective image. The former is created in the minds of tourists and depends on the quality and quantity of available information. The latter, by contrast, comprises the characteristics of the destination itself (Baloglu and Brinberg, 1997), since the information about this image is not only obtained from different sources, but also depends on the characteristics of each individual (Stern and Krakover, 1993; Beerli and Martín, 2004). Tourists can also form a third image - known as the unique image - when their experience with a destination leads them to find it distinct from all other destinations (Qu et al., 2011).

In this regard, information sources serve as an important antecedent of destination image (i.e., in the formation of this image), since travelers' perceptions of a destination can be influenced by the information they receive from different sources. The literature has widely studied the 
connection between the use of information sources and destination image formation (e.g., Li et al., 2009; Coromina and Camprubí, 2016; Draper, 2016). However, what truly matters is how consumers process the information, which can depend on the type of message they receive (Rodríguez-Molina et al., 2015).

In light of the above, the present study aims to develop and test a theoretical model of destination image formation that addresses the influence of information sources on the formation of a cultural destination's overall image - and specifically its different components (i.e., the cognitive, affective image, and unique images). Our aim is to study these image types more exhaustively and determine their role in the formation of a destination's overall image. At the same time, this conceptual model seeks to fill a gap in the literature regarding the unique image - namely, what role it plays in the overall image and how it is affected by information sources. Researchers have not previously considered the unique image dimension in relation to the image formation process for a cultural destination such as an archeological site. We collected our data at the Segóbriga Archeological Park in the province of Cuenca (Spain), an archeological heritage destination that is regarded as one of the best-preserved Roman cities in the Western Roman Empire. Park visitors can first take a tour of all the best-preserved structures at the heritage site (walls, thermal baths, theater, amphitheater, basilica, circus, forum, necropolis, etc.). They can then supplement the tour with a visit to the interpretation center, which offers tourists an idea of what the ancient city was like. The site was granted the status of archeological park in order to promote tourism in the area and, by extension, boost the local economy.

\section{CONCEPTUAL FRAMEWORK}

\section{Destination Image}

The concept of destination image has been extensively researched in tourism studies (Stepchenkova and Mills, 2010; Stepchenkova and Li, 2012; Cherifi et al., 2014; Sun et al., 2015; Fu et al., 2016), as well as in other disciplines such as sociology, environmental management and psychology (Tang, 2014), and marketing and consumer behavior (Sirakaya and Woodside, 2005; Stepchenkova and Morrison, 2008). There has also been a growing body of research on tourist destinations themselves (Gallarza et al., 2002), much of which builds on the work of Hunt (1971) (Witter, 1985; Gartnerand and Hunt, 1987; Embacher and Buttle, 1989; Reilly, 1990; Echtner and Ritchie, 1991; Fakeye and Crompton, 1991). These myriad studies speak to the fact that image is fundamental to tourism destination promotion (Hudson et al., 2011), since the ways a destination differentiates itself is key to its success (Cai, 2002; Qu et al., 2011; Carballo et al., 2015).

The last four decades have produced a large body of research that illuminates the magnitude or significance of a destination's image from different perspectives (Deng and Li, 2014). Destination image has been approached in terms of its dimension and conceptualization (Hunt, 1971, 1975; Gunn, 1972; Crompton, 1979; Gartner, 1989; Echtner and Ritchie, 1991; Baloglu and McCleary, 1999; Cai, 2002; Tasci et al., 2007; Tasci and Gartner, 2007; Stepchenkova and Morrison, 2008; Lai and Li, 2012,2016), its evaluation and measurement
(Gartner, 1989; Echtner and Ritchie, 1991, 1993, 2003; Fakeye and Crompton, 1991; Baloglu, 1998; Baloglu and McCleary, 1999; Beerli and Martín, 2004; Chen and Tsai, 2007; Stepchenkova and Morrison, 2008; Yang et al., 2012), changes in the image over time (e.g., Gartnerand and Hunt, 1987; Ahmed, 1991; Fakeye and Crompton, 1991; Kim and Morrsion, 2005), its management (e.g., Goodrich, 1978; Gartner, 1989; Baloglu, 1998; Konecnik and Gartner, 2007; Pike, 2009), its effect on tourists' behavior (Chaudhary, 2000; Sirakaya and Woodside, 2005; Tasci and Gartner, 2007), and its formation (Gartner, 1989; Chon, 1990; Echtner and Ritchie, 1991; Beerli and Martín, 2004; Royo-Vela, 2009). In all these approaches, the importance of image in a destination's tourism development is paramount (MartínSantana et al., 2017). However, destination image formation is probably the most important of these issues (Deng and Li, 2014), as it underlies all the others (Gallarza et al., 2002).

One of the first studies on image formation was conducted by Gunn (1972), which looked at only two dimensions of the formation process: the organic image and the induced image. The organic image is understood as that arising from non-commercial or uncontrolled information sources, such as the opinions of friends, magazines, newspapers, news, reports, etc. (i.e., sources not intended to promote the destination). In contrast, the induced image arises from commercial information sources (i.e., marketing efforts of various commercial agents to publicize a destination, such as travel brochures; Tasci and Gartner, 2007). According to Gunn (1972, 1988), an individual's image of a destination is constantly being reformed and renewed.

As a destination's tourism image is essential to attracting tourists, it is important that said image be as real and current as possible. Indeed, the destination image clearly influences tourists' behavior (Deng and Li, 2014), as it directly reflects visitors' perceived quality of a place, as well as their satisfaction (evaluation of the stay) with, intention to return to (future behavior) and recommend (attitudinal loyalty) the destination (Bigné et al., 2001).

\section{Components of the Destination Image}

Each tourist's individual perceptions can produce a relative and personal image a destination (Bigné et al., 2001; Gallarza et al., 2002; San Martín and del Bosque, 2008). In other words, tourists' opinions are highly subjective, formed around very different antecedents based on their individual thoughts and emotions. As a result, many authors have generally investigated tourism destination image on the basis of its cognitive and affective components. For tourists, the cognitive image represents their knowledge of and beliefs regarding a place, while the affective image refers to their feelings or emotional responses toward it (Gartner, 1994; Baloglu, 1998; Beerli and Martín, 2004; Pike and Ryan, 2004; Royo-Vela, 2009; San Martín and del Bosque, 2008, 2011; Maher and Carter, 2011; Smith et al., 2015). The combination of the affective and cognitive images gives rise to the overall image (Baloglu and McCleary, 1999). Notably, the overall image reflects not only the common or shared aspects, but also the unique images that render a place distinctive (Echtner and Ritchie, 2003). The unique characteristics of a destination include both tangible attributes (e.g., beaches or historical sites) and intangible ones (e.g., customs, culture, and 
history) (Qu et al., 2011). Therefore, the unique image helps to sharpen destinations' identities and thereby improve their competitive positioning (Lin and Kuo, 2018). However, few authors have examined this unique image component (e.g., Qu et al., 2011; Llodrà Riera, 2013; Lin and Kuo, 2018). The most important research on the topic has looked at only the two main components, i.e., the cognitive and affective images (Baloglu and Brinberg, 1997; Baloglu and McCleary, 1999; Kim and Richardson, 2003; Beerli and Martín, 2004; Hsu et al., 2004; Pike and Ryan, 2004; San Martín and del Bosque, 2008, 2011; Gutiérrez and del Bosque, 2010; Smith et al., 2015; Tan and Wu, 2016; Molinillo et al., 2018).

The present study will account for all three images types, with a special emphasis on the unique image. In this way, we hope to supplement the scant number of authors who have considered this third component in their work on destination image formation (e.g., Echtner and Ritchie, 1991; Qu et al., 2011; Llodrà Riera, 2013; Lin and Kuo, 2018). Below, we will briefly outline the research on all three image types before proceeding to discuss the role of each of them in the general image of Segóbriga.

(a) Cognitive image: Most studies have specifically considered the cognitive component of the image (Echtner and Ritchie, 1991; Echtner and Ritchie, 2003; Beerli and Martín, 2004; Chi and Qu, 2008; Sun et al., 2013). In fact, Pike (2002) found that of 142 papers published between 1973 and 2000, only six included the affective (or psychological) component. As noted, this dimension of the image refers to tourists' knowledge or beliefs about the destination's attributes (Baloglu and McCleary, 1999). The literature shows that this dimension arises from other elements, such as the natural environment, cultural resources, infrastructure, and quality. However, scholars differ on the importance they assign to these latter four factors (Baloglu and McCleary, 1999; Gallarza et al., 2002; Beerli and Martín, 2004; Chi and Qu, 2008; San Martín and del Bosque, 2008; Stylos et al., 2016; Stylidis et al., 2017). Some authors argue that these cultural and natural resources include particularities such as landscape beauty, cultural activities, or traditions and customs (e.g., Beerli and Martín, 2004; Stylos et al., 2016; Stylidis et al., 2017). Others maintain that these resources merely refer to attractions (e.g., Baloglu and McCleary, 1999).

(b) Affective image: To measure the affective image, many authors (e.g., Baloglu and McCleary, 1999; Bigné et al., 2001; Kim and Richardson, 2003; Beerli and Martín, 2004; Pike and Ryan, 2004; Chi and Qu, 2008; Nadeau et al., 2008; Alcañiz et al., 2009; Chen et al., 2016), have drawn on the work of Russell and Pratt (1980). Although the literature has spent less time addressing the affective component, it is particularly important for improving tourists' perception of the destination image (Moreno-Gil et al., 2012), as it reflects their feelings toward a destination (Chen et al., 2016). In line with feelings-as-information theory, which explains how individuals make use of their emotions and impressions in ways that predispose them toward a destination (Kock et al., 2016). Stylos et al. (2016) found that advertisements featuring emotional content (e.g., words such as exciting, pleasant and relaxing) convey a destination's affective image.

(c) Unique image: Considering that the tourism industry is marked by high competition and a relatively undifferentiated supply, Qu et al. (2011) found that it is necessary to identify the attributes that define a destination and make it unique in tourists' minds. Other authors (e.g., Lin and Kuo, 2018) have only considered this component in order to study the overall image. Specifically, they concluded that the unique image is important for marketing differentiation strategies and, by extension, improving a place's competitiveness. Thus, it appears that the unique image partly explains the influence of the affective image, meaning that the latter exerts a weaker effect on the overall image compared to the other two dimensions (cognitive and unique) (Qu et al., 2011). Hence, in the midst of increasing competition among tourist destinations, it is important to identify the attributes that characterize a cultural destination as unique and encourage tourists to perceive it as such.

\section{Information Sources in Image Formation}

In reviewing the literature on destination image, it becomes clear that information sources are important antecedents to all three image components. Some researchers have suggested that these sources influence the formation of the cognitive image, but not the affective one (Woodside and Lysonski, 1989; Gartner, 1994; Baloglu and McCleary, 1999). In other words, external sources more strongly affect cognitive beliefs regarding a destination (Um and Crompton, 1990). Likewise, Beerli and Martín (2004) found that both organic sources (family members and friends) and autonomous sources (travel guides, news, articles, reports or documentaries) influence certain cognitive factors of the positive image. However, other authors (e.g., Jeong et al., 2012) have found that the information route is one of the primary factors influencing the cognitive image or overall image of a destination.

In recent years, academics and professionals have come to realize the importance of the Internet in shaping destination image. The Internet has transformed traditional WOM into eWOM. The communication of opinions is no longer done interpersonally (i.e., person-to-person or face-to-face), but rather is mediated by ICT (Huete-Alcocer, 2017). Although previous studies have shown that the Internet influences both the cognitive and affective dimensions of the destination image, most of the literature has focused solely on the cognitive dimension (Alcázar and Sicilia, 2015). In this regard, it is important to note that constructing a tourist destination image online is a more dynamic social process than traditional methods of image projection (e.g., through printed brochures and guides). The online image is instead generated by other tourists posting photographs, comments, perceptions, and experiences related to the destination (Hunter, 2016). For example, Kim et al. (2017) found that social media are a source of emerging information in tourism destination marketing. However, the issue of tourism destination image formation on social media remains relatively unexplored, especially empirically (Kim et al., 2017). Some authors (e.g., Prats et al., 2016) have suggested that an official website positively influences cognitive evaluations, since the information offered through such sites must be provided in a practical way to enable preparation of the trip. By contrast, guides influence affective evaluations due to appealing mainly to tourists' emotions. Similarly, Martín-Santana et al. (2017) showed that the cognitive image is positively affected by high levels of online participation among tourists. Other authors (e.g., Molinillo et al., 2018) have found that tourist participation in online platforms 
positively impacts both the cognitive and affective images, and by extension, the intention to visit. Of course, image formation and the intention to visit vary according to the platform that travelers use to access the information (Molinillo et al., 2018). In general, most of the research agrees that the cognitive image somewhat informs the affective aspect, but the latter is also more difficult to change through external information (Li et al., 2009).

To our knowledge, no previous literature has sought to evaluate how information sources influence the unique image - and specifically that of an archeological destination. The present study aims to fill this gap, while also incorporating the cognitive and affective components.

\section{Proposed Model and Hypotheses}

Drawing on the literature review, this study analyzed the image of a particular cultural destination as a reflective, multidimensional concept (Jarvis et al., 2003). The proposed model was developed based on previous studies showing that a destination's image is fundamentally influenced by the cognitive and affective components, which are themselves influenced by the information sources that tourists utilize. The present study also analyzed the influence of the unique image component, in relation to both information sources and the overall image of an archeological heritage destination. We also considered the degree to which the cognitive and unique images influence the affective image. To this end, we propose the following conceptual model (Figure 1) and hypotheses:

Hypotheses $\mathrm{H} 1$ and $\mathrm{H} 2$ were formulated by drawing on Beerli and Martín (2004), Qu et al. (2011), and Llodrà Riera (2013). Hypothesis H1 aims to verify the influence of information sources on the formation of the different images: cognitive, affective, and unique. Its first source is the model proposed in Beerli and Martín (2004), which examined the role of information sources in the formation of cognitive and affective images. It second source is Qu et al. (2011), which included the unique image. Finally, it incorporates the study by Llodrà Riera (2013), which is one of the few other studies (outside of Echtner and Ritchie, 1991; Qu et al., 2011) to consider the unique image. Llodrà Riera (2013) also examined the role of information sources in the formation of the

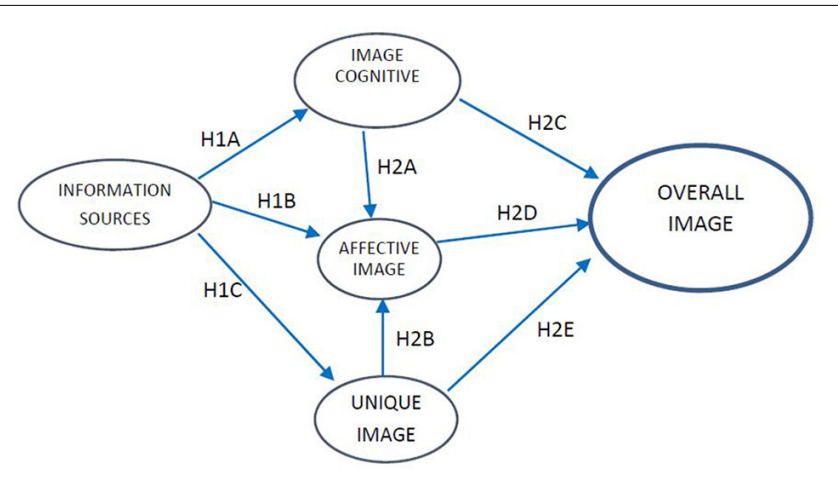

FIGURE 1 | Model for the formation of the image of a cultural destination. three types of images; however, that study referred to a sunand-sand destination. In light of these considerations, we propose the following hypothesis alongside three sub-hypotheses (H1A, H1B, and $\mathrm{H} 1 \mathrm{C})$ :

Hypothesis 1: The information sources used by tourists have a positive and significant influence on the cognitive, affective, and unique image.

H1A: Information sources positively and significantly influence the cognitive image.

H1B: Information sources positively and significantly influence the affective image.

H1C: Information sources positively and significantly influence the unique image.

In keeping with the above considerations and our objective (i.e., to analyze the formation of a cultural destination image), we relied on previous research (Beerli and Martín, 2004; Qu et al., 2011; Llodrà Riera, 2013) to formulate the second hypothesis $(\mathrm{H} 2)$, which consists of five sub-hypotheses ( $\mathrm{H} 2 \mathrm{~A}, \mathrm{H} 2 \mathrm{~B}, \mathrm{H} 2 \mathrm{C}$, $\mathrm{H} 2 \mathrm{D}$, and $\mathrm{H} 2 \mathrm{E})$. The aim of these sub-hypotheses was to analyze, first, how the cognitive image and unique image affect the affective image, and second, how each of these images (cognitive, affective, and unique) influences the destination's overall image.

Hypothesis 2: With regard to the positive and significant influence of the cognitive and unique image on the affective image of a destination, and to the positive and significant influence of each of these images (cognitive, affective, and unique) on the overall image of a destination:

H2A: the cognitive image positively and significantly influences the affective image.

$H 2 B$ : the unique image positively and significantly influences the affective image.

H2C: the cognitive image positively and significantly influences the overall image.

$H 2 D$ : the affective image positively and significantly influences the overall image.

H2E: the unique image positively and significantly influences the overall image.

\section{METHODOLOGY}

Of the many procedures used by various authors to analyze tourism destination images, we chose to use structural equation modeling (SEM) for this study. To this end, we found the PLS method to be the most efficient means of executing the SEM to test the proposed hypotheses.

\section{Data Collection Procedure}

We first designed a questionnaire for the purpose of collecting information from site visitors following their visit. We devised the questions based on a thorough review of the literature 
and the specific characteristics of the destination under study. We conducted a pilot test with the questionnaire in order to ensure the tool's clarity and relevance; only a few minor changes were made based on the results. The finalized survey was then administered to site visitors over a period of four consecutive weekends during the months of April and May 2017. A total of 598 questionnaires were given out to tourists aged 18 and over, resulting in a final sample of 511 valid responses.

A researcher handed out the questionnaires to the participants, gathered their consent, informed them about the study and procedure, and explained the meaning of some items. Participants were assured that their responses would remain anonymous and could be withdrawn from the study whenever they wanted. The authors will make the raw data available, without undue reservation, to any qualified researcher. With regard to ethics, the study was approved on March 15, 2017 by the Research Ethics Commission of the University of Castilla-La Mancha (chairperson: José Julian Garde López - Brea. Vice-chancellor's office for Research and Scientific Policy; secretary: Isabel Turégano Mansilla, Cuenca Faculty of Social Sciences; members: Inés Martínez Galán, Christian Gortázar Schmidt and Jorge Laborda Fernández).

\section{Variables and Measurement Scales}

Most of the constructs used in the present research are multidimensional concepts, each comprising several items. For all items, we employed a 5-point Likert scale as the measurement method. We analyzed a total of 32 items concerning information sources, including 19 about traditional sources and 13 about online ones (Tables 1, 2, respectively).

When carrying out the CFA for the information sources (traditional and online), only seven factors emerged, which grouped several items eliminating those whose value of lambda was less than 0.5: SOURINF1 (scientific articles of Segóbriga, news, reports and documentaries and books), SOURINF2 (media specialized in tourism, media specialized in archeological heritage, travel guides, fairs and TV series and movies), SOURINF3 (only WOM), SOURINF4 (promotion agencies, Web of the Diputación of Cuenca, Web JCCM and Web tourism of Castilla-La Mancha), SOURINF5 (Webs with user ratings and forums) SOURINF6 (blogs and Webs of tourism business Cuenca) and SOURINF7 (Internet browser and Google Maps).

Table 3 shows the variables used to measure the cognitive dimension, which were based on Beerli and Martín (2004) and $\mathrm{Qu}$ et al. (2011). While numerous studies clearly signal that this dimension comprises the natural environment, cultural resources, infrastructure, and quality, the importance assigned to each varies (e.g., Baloglu and McCleary, 1999; Gallarza et al., 2002; Beerli and Martín, 2004; Chi and Qu, 2008; San Martín and del Bosque, 2008). For example, while some authors (e.g., Beerli and Martín, 2004) suggest that cultural resources are features of landscape beauty, traditions, customs or cultural activities themselves, others (e.g., Baloglu and McCleary, 1999) consider such resources to be mere attractions.

On the other hand, the CFA for the cognitive image only revealed six factors after we eliminated items whose lambda value was less than 0.5: COGNITIVE1 corresponds to the
TABLE 1 | Traditional information sources construct.

\begin{tabular}{|c|c|c|}
\hline Questionnaire question & Item & Acronym \\
\hline \multirow{4}{*}{$\begin{array}{l}\text { 1. Indicate the extent to } \\
\text { which you have used the } \\
\text { following traditional } \\
\text { information sources to } \\
\text { obtain information about } \\
\text { Segóbriga Archeological } \\
\text { Park. }\end{array}$} & Tourist brochures & TSOURCE1 \\
\hline & $\begin{array}{l}\text { Travel agencies or tour operator } \\
\text { tour }\end{array}$ & TSOURCE2 \\
\hline & $\begin{array}{l}\text { Public figures with a recognized } \\
\text { audience }\end{array}$ & TSOURCE3 \\
\hline & Scientific papers on Segóbriga & TSOURCE4 \\
\hline \multirow{15}{*}{$\begin{array}{l}\text { SCALE: } 1=\text { I did not use it } \\
\text { at all. } 5 \text { = It was one of my } \\
\text { main sources of } \\
\text { information. } \\
\text { Authors: Gunn, 1988; } \\
\text { Gartner, 1994; Bigné et al., } \\
\text { 2001; Beerli and Martín, } \\
\text { 2004; Llodrà Riera, } 2013\end{array}$} & News, reports and documentaries & TSOURCE5 \\
\hline & $\begin{array}{l}\text { Tourist information from agencies } \\
\text { that promote the destination (e.g., } \\
\text { ADESIMAN, Ministry of Education, } \\
\text { Culture and Sports, Ministry of } \\
\text { Tourism, Trade and Crafts) }\end{array}$ & TSOURCE6 \\
\hline & $\begin{array}{l}\text { Schools (primary schools, } \\
\text { universities, vocational schools) }\end{array}$ & TSOURCE7 \\
\hline & $\begin{array}{l}\text { Nearby accommodations, } \\
\text { supplementary offer }\end{array}$ & TSOURCE8 \\
\hline & Specialized tourism media & TSOURCE9 \\
\hline & $\begin{array}{l}\text { Specialized archeological heritage } \\
\text { media }\end{array}$ & TSOURCE10 \\
\hline & Books & TSOURCE11 \\
\hline & Travel guides & TSOURCE12 \\
\hline & Fairs & TSOURCE13 \\
\hline & TV shows and movies & TSOURCE14 \\
\hline & Radio & TSOURCE15 \\
\hline & The Internet & TSOURCE16 \\
\hline & Friends and family & TSOURCE17 \\
\hline & Local residents & TSOURCE18 \\
\hline & $\begin{array}{l}\text { The sign located on the A-3 } \\
\text { highway: Madrid - Valencia - } \\
\text { Alicante. }\end{array}$ & TSOURCE19 \\
\hline
\end{tabular}

measured variable of natural resources (climate and richness of the landscape); COGNITIVE2 with tourist infrastructures (restaurants, hotels and accommodation); COGNITIVE3 with elements of the culture, history and art (monuments, museum and pieces, historical constructions, customs and ways of life); COGNITIVE4 includes another five items of the variable culture, history and art (gastronomy, theater festivals, concerts, crafts and folklore); COGNITIVE5 corresponds to the variable natural environment, measured by the maintenance and conservation of the deposit; and finally, COGNITIVE6 reflects the social environment (hospitality and friendliness of local residents and quality of life in the area).

We drew on several studies, most of them built on the findings of Russel and Pratt, to measure the affective image (e.g., Baloglu and McCleary, 1999; Bigné et al., 2001; Kim and Richardson, 2003; Beerli and Martín, 2004; Pike and Ryan, 2004; Chi and Qu, 2008; Nadeau et al., 2008; Alcañiz et al., 2009; Chen et al., 2016; Stylos et al., 2016; Stylidis et al., 2017). These studies, in turn, built on the findings of Russell and Pratt (1980). Table 4 shows the attributes that we considered.

With regard to measuring the unique image dimension, we drew on three previous studies: namely, Echtner and Ritchie 
TABLE 2 | Online information sources construct.

\begin{tabular}{|c|c|c|}
\hline Questionnaire question & Item & Acronym \\
\hline \multirow{4}{*}{$\begin{array}{l}\text { 2. Indicate the extent to } \\
\text { which you used the } \\
\text { following online information } \\
\text { sources to obtain } \\
\text { information about } \\
\text { Segóbriga Archeological } \\
\text { Park. }\end{array}$} & $\begin{array}{l}\text { Official website of the site } \\
\text { (www.segóbriga.org) }\end{array}$ & ONSOURCE1 \\
\hline & $\begin{array}{l}\text { Official website of the site } \\
\text { (www.spaincenter.org) }\end{array}$ & ONSOURCE2 \\
\hline & $\begin{array}{l}\text { Social media (Facebook, Twitter, } \\
\text { Instagram, etc.) }\end{array}$ & ONSOURCE3 \\
\hline & Blogs & ONSOURCE4 \\
\hline \multirow{2}{*}{$\begin{array}{l}\text { SCALE: } 1=\text { I did not use it } \\
\text { at all. } 5=\text { It was one of my } \\
\text { main sources of information }\end{array}$} & $\begin{array}{l}\text { Websites with user ratings } \\
\text { (TripAdvisor) }\end{array}$ & ONSOURCE5 \\
\hline & $\begin{array}{l}\text { Websites of tourism companies in } \\
\text { Cuenca that offer it }\end{array}$ & ONSOURCE6 \\
\hline \multirow{7}{*}{$\begin{array}{l}\text { Authors: Llodrà Riera, } \\
\text { 2013; Zeng and Gerritsen, } \\
\text { 2014; Llodrà-Riera et al., } \\
\text { 2015; Tseng et al., 2015; } \\
\text { Coromina and Camprubí, } \\
2016\end{array}$} & $\begin{array}{l}\text { Website of the Provincial } \\
\text { Government of Cuenca }\end{array}$ & ONSOURCE7 \\
\hline & $\begin{array}{l}\text { Website of the Regional } \\
\text { Government of Castilla-La Mancha } \\
\text { (www.patrimoniohistoricoclm.es) }\end{array}$ & ONSOURCE8 \\
\hline & $\begin{array}{l}\text { Official Castilla-La Mancha tourism } \\
\text { website } \\
\text { (www.turismocastillalamancha.es) }\end{array}$ & ONSOURCE9 \\
\hline & $\begin{array}{l}\text { Internet search engines (Google, } \\
\text { Bing, Yahoo, etc.) }\end{array}$ & ONSOURCE10 \\
\hline & $\begin{array}{l}\text { Maps (Google Maps, ViaMichelín, } \\
\text { Guía Repsol, etc.) }\end{array}$ & ONSOURCE11 \\
\hline & Forums (Los Viajeros, TripAdvisor) & ONSOURCE12 \\
\hline & Video-sharing apps (YouTube) & ONSOURCE13 \\
\hline
\end{tabular}

(1991), Qu et al. (2011), and Llodrà Riera (2013) (Table 5). This variable captures the characteristics of the site that visitors regard as unique relative to other archeological parks. The associated CFA revealed only three factors for the unique image (all except UNIMA 1).

The CFA of the affective image revealed only three factors: AFFIMA1, AFFIMA3, and AFFIMA5 (Table 6).

Finally, we measured the site's overall image using a single question based on Baloglu and McCleary (1999): "After your visit, rate the site's overall image." Respondents had to score the question on a 5-point Likert scale ( $1=$ Very bad/5 = Very good).

The survey concluded with a final set of questions related to respondents' demographics, such as age, income level, gender, education, overnight stay in the area, place of origin, etc. Based on this data, we verified the profile of the typical tourist to Segóbriga: a middle-aged (between 40 and 59 years old) person, most often a woman, who works for someone else, has a higher education, and earns a rather high income.

\section{ANALYSIS OF RESULTS}

\section{Evaluation of the Measurement Model: Validity and Reliability}

Before testing the proposed hypotheses, we evaluated the measurement model with PLS (Barclay et al., 1995). Specifically, we employed SmartPLS 3.0 software to analyze the individual reliability of each item, the reliability of the scale, and the convergent and discriminant validity. We obtained the
TABLE 3 | Cognitive image construct.

\begin{tabular}{|c|c|c|c|}
\hline $\begin{array}{l}\text { Questionnaire } \\
\text { question }\end{array}$ & Variable & Item & Acronym \\
\hline $\begin{array}{l}\text { 3. Rate the quality } \\
\text { of each of these } \\
\text { elements: }\end{array}$ & $\begin{array}{l}\text { Natural } \\
\text { resources }\end{array}$ & $\begin{array}{l}\text { Weather } \\
\text { Richness of the landscape }\end{array}$ & COGIMA2 \\
\hline $\begin{array}{l}\text { SCALE: } 1=\text { Most } \\
\text { negative score }\end{array}$ & $\begin{array}{l}\text { General } \\
\text { infrastructure }\end{array}$ & $\begin{array}{l}\text { Ability to access the } \\
\text { archeological park by } \\
\text { public transport }\end{array}$ & COGIMA3 \\
\hline $\begin{array}{l}5=\text { Most positive } \\
\text { score }\end{array}$ & & $\begin{array}{l}\text { Ability to access the } \\
\text { archeological park by } \\
\text { private transport }\end{array}$ & COGIMA4 \\
\hline $\begin{array}{l}\text { Authors: Beerli } \\
\text { and Martín, 2004; } \\
\text { Qu et al., 2011; } \\
\text { Stylos et al., 2016; } \\
\text { Stylidis et al., 2017 }\end{array}$ & $\begin{array}{l}\text { Tourism } \\
\text { infrastructure }\end{array}$ & $\begin{array}{l}\text { Accessibility inside the site } \\
\text { Restaurants } \\
\text { Hotels and } \\
\text { accommodations }\end{array}$ & $\begin{array}{l}\text { COGIMA5 } \\
\text { COGIMA6 } \\
\text { COGIMA7 }\end{array}$ \\
\hline
\end{tabular}

\section{Ease of obtaining tourist} information at the archeological park

Leisure and
recreation
tourism

Activities within the archeological park (educational and leisure activities, sports events such as races, photography contests, exhibitions)

Culture, history
and art

$$
\text { Monuments }
$$

Museum and pieces Historical constructions Customs and ways of life Food

Theater festivals Concerts

Crafts

Folklore

Guided tours of the archeological park

\begin{tabular}{|c|c|}
\hline \multirow[t]{4}{*}{$\begin{array}{l}\text { Natural } \\
\text { environment }\end{array}$} & $\begin{array}{l}\text { Maintenance and } \\
\text { conservation }\end{array}$ \\
\hline & Cleaning \\
\hline & $\begin{array}{l}\text { Security service at the } \\
\text { archeological park }\end{array}$ \\
\hline & Attractiveness of the site \\
\hline \multirow[t]{2}{*}{$\begin{array}{l}\text { Social } \\
\text { environment }\end{array}$} & $\begin{array}{l}\text { Hospitality and friendliness } \\
\text { of local residents }\end{array}$ \\
\hline & Local quality of life \\
\hline $\begin{array}{l}\text { Political and } \\
\text { economic } \\
\text { factors }\end{array}$ & $\begin{array}{l}\text { Value for money of the } \\
\text { admission to the } \\
\text { archeological park }\end{array}$ \\
\hline
\end{tabular}

COGIMA10 COGIMA11 COGIMA12 COGIMA13 COGIMA14 COGIMA15 COGIMA16 COGIMA17 COGIMA18 COGIMA19 COGIMA20 COGIMA21 COGIMA22

COGIMA23 COGIMA24

COGIMA25

COGIMA26 economic admission to the significance of the parameters through bootstrapping, which assesses the accuracy of the PLS estimates (Hair et al., 2011).

\section{The Individual Reliability of Each Item}

The individual reliability of each indicator was calculated, and the simple correlations of the means with their constructs were analyzed. Those items with a factor loading greater than or equal to 0.707 (meaning that more than $50 \%$ of the observed variable's variance was shared with the construct) were considered reliable (Carmines and Zeller, 1979). 
TABLE 4 | Affective image construct.

\begin{tabular}{|c|c|c|c|}
\hline $\begin{array}{l}\text { Questionnaire } \\
\text { question }\end{array}$ & Authors & Item & Acronym \\
\hline \multirow{6}{*}{$\begin{array}{l}\text { 4. Indicate the degree } \\
\text { to which you agree or } \\
\text { disagree with the } \\
\text { following statements. } \\
\text { Segóbriga } \\
\text { Archeological Park is: }\end{array}$} & \multirow{2}{*}{$\begin{array}{l}\text { Hosany et al., 2007; Qu et al., } \\
2011\end{array}$} & Beautiful & AFFIMA1 \\
\hline & & Ugly & AFFIMA2 \\
\hline & \multirow{8}{*}{$\begin{array}{l}\text { Baloglu and McCleary, 1999; } \\
\text { Bigné et al., 2001; Kim and } \\
\text { Richardson, 2003; Beerli and } \\
\text { Martín, 2004; Pike and Ryan, } \\
\text { 2004; Chi and Qu, 2008; } \\
\text { Nadeau et al., 2008; Alcañiz } \\
\text { et al., 2009; Chen et al., } \\
\text { 2016; Stylos et al., 2016; } \\
\text { Stylidis et al., } 2017\end{array}$} & Nice & AFFIMA3 \\
\hline & & Unpleasant & AFFIMA4 \\
\hline & & Relaxing & AFFIMA5 \\
\hline & & Stressful & AFFIMA6 \\
\hline \multirow{4}{*}{$\begin{array}{l}\text { SCALE: } 1 \text { = Strongly } \\
\text { disagree } 5 \text { = Strongly } \\
\text { agree }\end{array}$} & & Fun & AFFIMA7 \\
\hline & & Boring & AFFIMA8 \\
\hline & & Exciting & AFFIMA9 \\
\hline & & Depressing & AFFIMA10 \\
\hline
\end{tabular}

TABLE 5 | Unique image construct.

\begin{tabular}{|c|c|c|c|}
\hline $\begin{array}{l}\text { Questionnaire } \\
\text { question }\end{array}$ & Authors & Item & Acronym \\
\hline $\begin{array}{l}\text { 5. Would you say that } \\
\text { Segóbriga } \\
\text { Archeological Park } \\
\text { offers a unique } \\
\text { experience in the }\end{array}$ & $\begin{array}{l}\text { Echtner and } \\
\text { Ritchie, 1991; } \\
\text { Qu et al., 2011; } \\
\text { Llodrà Riera, } \\
2013\end{array}$ & $\begin{array}{l}\text { When sports } \\
\text { activities are } \\
\text { held there. }\end{array}$ & UNIMA1 \\
\hline $\begin{array}{l}\text { following cases? } \\
\text { SCALE: } 1 \text { = Strongly } \\
\text { disagree } 5 \text { = Strongly } \\
\text { agree }\end{array}$ & & $\begin{array}{l}\text { When cultural } \\
\text { activities are } \\
\text { held there (e.g., } \\
\text { conferences, } \\
\text { plays, etc.) }\end{array}$ & UNIMA2 \\
\hline $\begin{array}{l}\text { 6. Do you agree that } \\
\text { the visit to the } \\
\text { archeological park's } \\
\text { interpretation center } \\
\text { offered a unique } \\
\text { experience? }\end{array}$ & & & UNIMA3 \\
\hline \multicolumn{4}{|l|}{$\begin{array}{l}\text { SCALE: } 1 \text { = Strongly } \\
\text { disagree } 5 \text { = Strongly } \\
\text { agree }\end{array}$} \\
\hline $\begin{array}{l}\text { 7. Do you agree that } \\
\text { the visit to Segóbriga } \\
\text { Archeological Park was } \\
\text { a unique experience } \\
\text { compared to other } \\
\text { parks? }\end{array}$ & & & UNIMA4 \\
\hline $\begin{array}{l}\text { SCALE: } 1 \text { = Strongly } \\
\text { disagree } 5 \text { = Strongly } \\
\text { agree }\end{array}$ & & & \\
\hline
\end{tabular}

\section{Composite Reliability}

Next, we calculated the composite reliability using Cronbach's alpha (Cronbach, 1951), which assesses whether the indicators measure the construct to which they are assigned. Table 7 shows that all the constructs met the threshold for reliability (i.e., a Cronbach's alpha value equal to or greater than 0.7 ).

\section{Convergent and Discriminant Validity}

First, we assessed the convergent validity by calculating the average variance extracted (AVE) for each construct (Fornell and Larcker, 1981). According to Fornell and Larcker (1981), this measure reflects a construct's amount of variance due to its indicators versus mere measurement error. Its value should be equal to or greater than 0.5 , which indicates that each construct explains at least $50 \%$ of the assigned indicators' variance. We also calculated rho_A, which is another of the most important reliability measures for PLS (Dijkstra and Henseler, 2015; Table 8).

Subsequently, we checked the discriminant validity, which captures the extent to which a given construct is different from the others in the model. This validity requires that

TABLE 6 | Measurement instrument: individual reliability.

\begin{tabular}{lcc}
\hline Factor & Indicator & Loading \\
\hline INFORMATION SOURCES & SOURINF1 & 0.998 \\
& SOURINF2 & 0.998 \\
& SOURINF3 & 0.708 \\
& SOURINF4 & 0.997 \\
& SOURINF5 & 0.996 \\
& SOURINF6 & 0.999 \\
COGNITIVE IMAGE & SOURINF7 & 0.953 \\
& COGNITIVE1 & 0.889 \\
& COGNITIVE2 & 0.960 \\
AFFECTIVE IMAGE & COGNITIVE3 & 0.977 \\
& COGNITIVE4 & 0.964 \\
& COGNITIVE5 & 0.972 \\
UNIQUE IMAGE & COGNITIVE6 & 0.880 \\
OVERALL IMAGE & AFFIMA1 & 0.868 \\
N/A, Not applicable to these variables as they were measured with a single item & \\
and thus would have a value of 1. & AFFIMA3 & 0.880 \\
& AFFIMA5 & 0.744 \\
& UNIMA2 & 0.701 \\
& UNIMA3 & 0.873 \\
& UNIMA4 & 0.855 \\
& N/A & N/A \\
\hline
\end{tabular}

TABLE 7 | Measurement instrument: composite reliability.

\begin{tabular}{lcc}
\hline Factor & Cronbach's alpha & Composite Reliability \\
\hline Information sources & 0.983 & 0.986 \\
Cognitive image & 0.974 & 0.979 \\
Affective image & 0.780 & 0.871 \\
Unique image & 0.733 & 0.849 \\
Overall image & 1.000 & 1.000 \\
\hline
\end{tabular}

TABLE 8 | Measurement instrument: convergent validity.

\begin{tabular}{lcc}
\hline Factor & AVE & Rho_A \\
\hline Information sources & 0.912 & 1.000 \\
Cognitive image & 0.886 & 0.992 \\
Affective image & 0.694 & 0.810 \\
Unique image & 0.654 & 0.764 \\
Overall image & 1.000 & 1.000
\end{tabular}


TABLE 9 | Measurement instrument: discriminant validity (Fornell-Larcker criterion).

\begin{tabular}{lccccc}
\hline & $\begin{array}{c}\text { Information Cognitive } \\
\text { sources }\end{array}$ & $\begin{array}{c}\text { Affective } \\
\text { image }\end{array}$ & $\begin{array}{c}\text { Unique } \\
\text { image }\end{array}$ & $\begin{array}{c}\text { Overall } \\
\text { image }\end{array}$ \\
\hline Information sources & $\mathbf{0 . 9 5 5}$ & & & & \\
Cognitive image & 0.073 & $\mathbf{0 . 9 4 1}$ & & & \\
& $(0.055)$ & & & & \\
Affective image & -0.072 & 0.359 & $\mathbf{0 . 8 3 3}$ & & \\
Unique image & $(0.079)$ & $(0.415)$ & & & \\
& 0.029 & 0.339 & 0.403 & $\mathbf{0 . 8 0 9}$ & \\
Overall image & $(0.055)$ & $(0.351)$ & $(0.477)$ & & $\mathbf{1 . 0 0 0}$ \\
& -0.048 & 0.337 & 0.525 & 0.570 & \\
& $(0.044)$ & $(0.357)$ & $(0.582)$ & $(0.650)$ & \\
\hline
\end{tabular}

Bolded values on the diagonal are the square root of the AVE of the corresponding construction.

the variance shared by a variable and its indicators must be greater than the variance shared with the model's other variables (Barclay et al., 1995). There are two evaluation methods: an analysis of the cross-loadings or through the correlations of the latent variables (AVE). The present research used the latter method, as can be seen in Table 9, which shows the data from the correlation matrix between the model's constructs (Table 9). The diagonal of the matrix shows the value of the square root of the AVE of the corresponding construct (bolded values in Table 9). As can be seen, the correlations between the constructs were less than the square root of the AVE. Therefore the constructs met the requirement for discriminant validity. Additionally, to check that measuring instrument, we also calculated the HTMT values: As Table 9 evidences, the values were consistently less than 0.9 (Gold et al., 2001).

\section{Evaluation of the Structural Model}

Table 10 displays the results of the structural analysis carried out with PLS. The path coefficients $(\beta)$ indicate the relationships between the structures, as well as the significance of these relationships. In order to study the stability and significance of the estimated parameters, we applied the aforementioned nonparametric resampling technique: bootstrapping. This technique involves creating a number of bootstrap samples through a randomized repeated sampling of the original sample (Hair et al., 2011).

As Table 10 indicates, all the accepted direct effects held true at a significance level of 99\%. These results allowed us to draw the following conclusions: First, we found support for sub-hypothesis H1A, which sought to verify whether information sources had a positive and significant influence on the cognitive image $(\beta=0.073, p<0.001)$. However, the support for sub-hypothesis $\mathrm{H} 1 \mathrm{~B}$ - which sought to confirm the influence and significance of information sources with regard to the affective image - diverged from our expectations $(\beta=-0.1, p<0.001)$. As can be seen, the data were significant, but the sign of the coefficient was negative. In other words, the influence of one variable on the other was negative. This may be because the relationship between the two variables is very weak or is being impacted by a mediating variable. Finally, we found no support for sub-hypothesis H1C, which sought to test the positive and significant influence of information sources on the unique image $(\beta=0.029, p>0.001$, $p>0.01, p>0.05)$. Specifically, the coefficient was not significantly different from zero, since the empirical value of $t$ was less than the critical value of $t$ for significance levels of $0.90,0.95$, and 0.99 .

With regard to the second hypothesis ( $\mathrm{H} 2)$, we found support for all five sub-hypotheses (H2A, H2B, H2C, H2D, and H2E). Thus, we confirmed that the cognitive image has a positive and significant influence on the affective image $(\mathrm{H} 2 \mathrm{~A})(\beta=0.259$, $p<0.001)$, as does the unique image $(\mathrm{H} 2 \mathrm{~B})(\beta=0.318, p<0.001)$. Meanwhile, the cognitive (H2C) $(\beta=0.080 ; p<0.001)$, affective (H2D) $(\beta=0.331 ; p<0.001)$, and unique image $(\mathrm{H} 2 \mathrm{E})$ $(\beta=0.409 ; p<0.001)$ all exerted a significant effect on the overall image.

In order to assess the structural model, we calculated R2 (Table 11). According to Falk and Miller (1992), the explained variance of the endogenous variables (R2) should be equal to or greater than 0.1 . However, an increasingly common alternative to solely considering R2 is the predictive relevance criterion Q2, proposed by Chin (1998): 318: Q2 measures how well the studied values can be reconstructed by the model and its parameters. If Q2 is greater than zero, the model has predictive relevance; if it is less than or equal to zero, it does not. But this is a rule-ofthumb that does not take into account the sampling distribution

\begin{tabular}{|c|c|c|c|c|}
\hline Hypothesis & $\begin{array}{l}\text { Structural } \\
\text { relationship }\end{array}$ & $\begin{array}{c}\text { Standardized } \\
\text { path }(\beta)\end{array}$ & $\begin{array}{c}\text { Bootstrap } \\
t \text {-value }\end{array}$ & $\begin{array}{l}\text { Support for } \\
\text { hypothesis }\end{array}$ \\
\hline $\mathrm{H} 1 \mathrm{~A}$ & $\begin{array}{c}\text { Information } \\
\text { sources } \rightarrow \text { Cognitive } \\
\text { image }\end{array}$ & 0.073 & 5,293 & SUPPORTED \\
\hline $\mathrm{H} 1 \mathrm{~B}$ & $\begin{array}{l}\text { Information sources } \\
\rightarrow \text { Affective image }\end{array}$ & -0.100 & 5,255 & SUPPORTED (-) \\
\hline $\mathrm{H} 1 \mathrm{C}$ & $\begin{array}{c}\text { Information } \\
\text { sources } \rightarrow \text { Unique } \\
\text { image }\end{array}$ & 0.029 & 1,493 & $\begin{array}{c}\text { NOT } \\
\text { SUPPORTED }\end{array}$ \\
\hline $\mathrm{H} 2 \mathrm{~A}$ & $\begin{array}{c}\text { Cognitive } \\
\text { image } \rightarrow \text { Affective image }\end{array}$ & 0.259 & 19,537 & SUPPORTTED \\
\hline $\mathrm{H} 2 \mathrm{~B}$ & $\begin{array}{l}\text { Unique image } \rightarrow \\
\text { Affective image }\end{array}$ & 0.318 & 20,731 & SUPPORTED \\
\hline $\mathrm{H} 2 \mathrm{C}$ & $\begin{array}{l}\text { Cognitive image } \\
\rightarrow \text { Overall image }\end{array}$ & 0.080 & 5,729 & SUPPORTED \\
\hline $\mathrm{H} 2 \mathrm{D}$ & $\begin{array}{l}\text { Affective image } \\
\rightarrow \text { Overall image }\end{array}$ & 0.331 & 22,641 & SUPPORTED \\
\hline $\mathrm{H} 2 \mathrm{E}$ & $\begin{array}{c}\text { Unique image } \rightarrow \text { Overall } \\
\text { image }\end{array}$ & 0.409 & 27,841 & SUPPORTED \\
\hline
\end{tabular}

TABLE 11 | Predictive relevance of the model.

\begin{tabular}{lcc}
\hline Factor & $\boldsymbol{R}^{\mathbf{2}}$ & $\boldsymbol{Q}^{\mathbf{2}}$ \\
\hline Information sources & 0.000 & 0.000 \\
Cognitive image & 0.005 & 0.002 \\
Affective image & 0.229 & 0.145 \\
Unique image & 0.001 & 0.001 \\
Overall image & 0.434 & 0.410
\end{tabular}


of Q2 (Shmueli et al., 2016; Arias-Oliva et al., 2019). As shown in Table 11, the R2 values were greater than 0.1 for all the variables except the cognitive image and the unique image. Likewise, all the Q2 values were greater than zero. Therefore, we can confirm that the model has predictive relevance.

Finally, we calculated the value of the standardized root mean square residual (SRMR) (Henseler et al., 2015) in order to measure the model's fit and compare the difference between the observed and predicted correlations. Values less than 0.08 are considered acceptable. Our proposed model achieved a value of 0.048 and thus had an appropriate fit. Figure 2 below illustrates the resulting SEM model.

\section{DISCUSSION}

Like other authors (e.g., Beerli and Martín, 2004; Llodrà Riera, 2013), we could only verify that information sources have a positive and significant influence on the cognitive image (sub-hypothesis H1A). Meanwhile, information sources had a significant negative impact on the affective image (H1B) and no significant impact on the unique image (H1C). These results are largely contrary to those obtained by Llodrà Riera (2013), who found support for all three sub-hypotheses.

In line with previous reports (e.g., Baloglu and McCleary, 1999; Beerli and Martín, 2004; Qu et al., 2011; Llodrà Riera, 2013), the results showed that cognitive image positively influences the overall image (H2C). Likewise, the influence of the cognitive image on the affective image ( $\mathrm{H} 2 \mathrm{~A})$ was consistent with previous findings (Baloglu and McCleary, 1999; Beerli and Martín, 2004). The fact that the affective image clearly influenced the overall image (H2D) confirms the findings of Baloglu and McCleary (1999), Beerli and Martín (2004), Ekinci and Hosany (2006), Qu et al. (2011), and Papadimitriou et al. (2015). Collectively, these findings suggest that the affective image can have a very significant direct effect on the overall image. Additionally, we found that the unique image influences both the affective (H2B) and overall image (H2E). Interestingly, its effect on the overall image was even greater than that of the affective image, although the latter has received considerably more attention in the literature. This is consistent with the findings of $\mathrm{Qu}$ et al. (2011), but not of Llodrà Riera (2013), the latter of whom was unable to confirm the relationships between the unique, affective, and overall images.

\section{CONCLUSION}

This study sought to examine the image formation of a particular cultural and tourism destination, Segóbriga Archeological Park. Both the theoretical review of the concept and the accompanying quantitative studies revealed that the overall image of this destination is a multidimensional phenomenon consisting of cognitive, affective, and unique dimensions. In other words, tourists form perceptions of Segóbriga based on not only their individual knowledge and beliefs regarding the site's characteristics, but also their feelings toward and perceptions of the destination as a unique experience. The results also illuminate that the unique image influenced the affective image more than the cognitive one. Additionally, the unique image had the greatest influence on the overall image (followed by affective and then cognitive). The fact that the unique image significantly influenced the overall image is consistent with the findings of Echtner and Ritchie (1993), who noted that the unique image is an excellent source of differentiation that can help improve the overall image.

Likewise, our study verified the role played by information sources in image formation. By analyzing the influence of these sources on the three dimensions of the image (cognitive, affective, and unique), we found that they positively and significantly influence the cognitive image, negatively influence the affective image, and do not seem to significantly influence the unique image.

The results also underscore the information sources most often used by tourists who visit this type of site: The top-ranking one was the Internet (an induced source), followed by word of mouth (WOM) from friends and family (an organic source). These sources thus carry the greatest weight in the destination image formation process. Consequently, tourism promotion and management would be best served by leveraging online sources (social media, websites, etc.) that allow users to post-comments (eWOM) that might be seen by potential future tourists. In short, eWOM is a powerful means of promoting tourism.

\section{Practical and Theoretical Implications}

The above findings constitute a novel contribution to the literature. First, the present study highlights the importance of the affective image. This stands in contrast to most research to date, which has placed more emphasis on the cognitive image. Second, we provide a test of the unique image dimension, which has largely been ignored in the literature. To this end, we confirmed that the unique image is an essential component of the overall image for an archeological destination. These practical implications align with those of Qu et al. (2011), who argued that tourists form a unique image impression following their visits, which helps to distinguish a destination in their minds. Thus, it appears that the unique image can bolster marketing differentiation strategies and make a destination more competitive (Lin and Kuo, 2018). Consequently, academics should continue researching this image component in relation to other tourist destinations.

Moreover, destination managers should take into account that potential and actual tourists are increasingly using the Internet to find information or post-comments on social media. In our study, respondents assigned the highest scores to the destination's website, to search engines (such as Google, Bing, or Yahoo), and to online map services (such as Google Maps, ViaMichelín, or Repsol Guide). Based on these results and the prior literature, we can safely conclude that information sources can be leveraged as promotional tools to positively influence a destination's image formation.

In conclusion, this research analyzed the factors that influence tourists' perceived images of an archeological park. In aiming to improve the future management of such sites, our results 


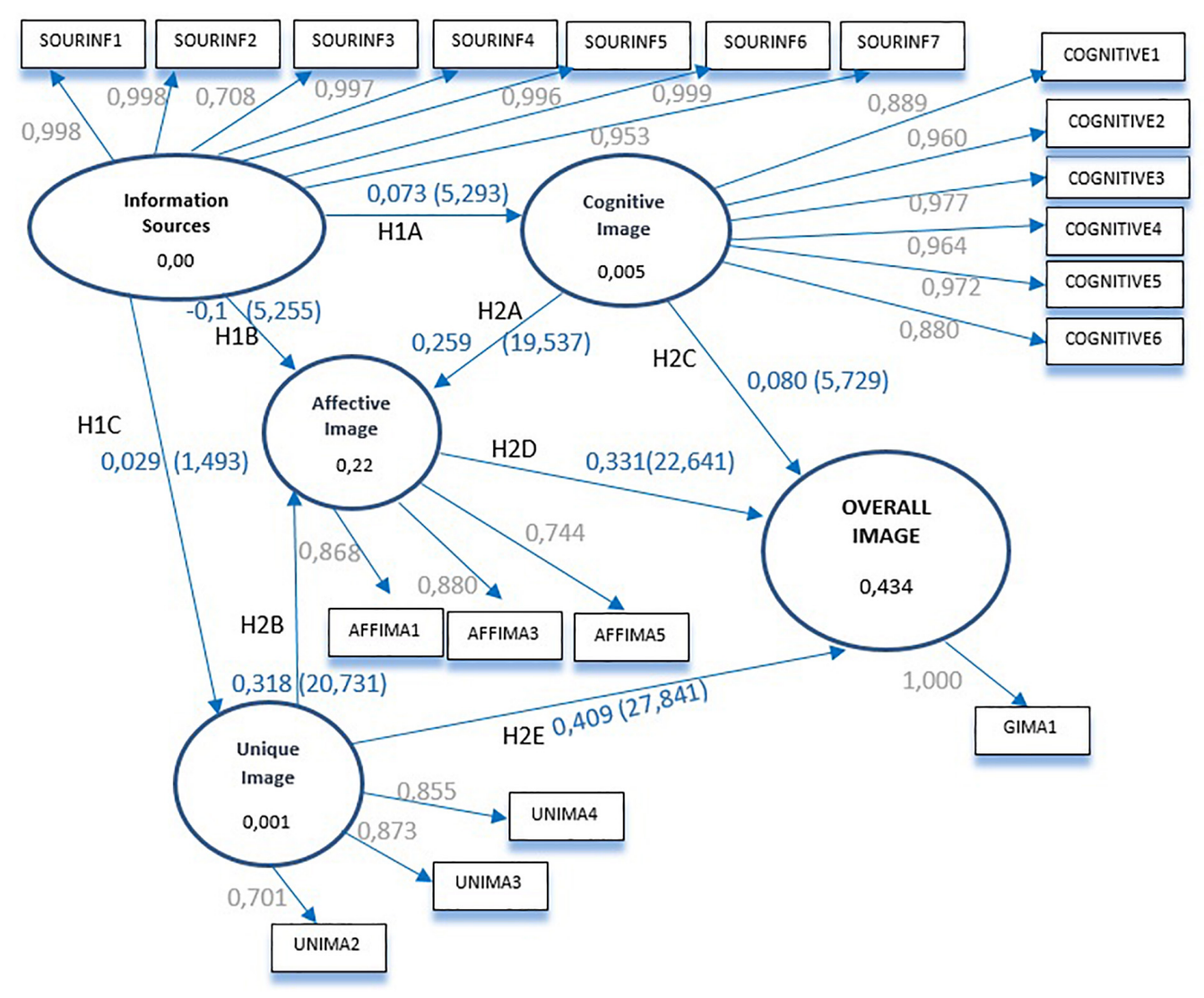

FIGURE 2 | Result of the model SEM.

highlight ways of attracting potential tourists, encouraging recommendations, and increasing the intention to return.

\section{Limitations and Further Research}

The present study features several limitations worth highlighting. For practical purposes, we measured the constructs from before and after the visit at the same time (i.e., following respondents' visit to the site). Consequently, it was not possible to gauge respondents' assessments of the site's image prior to their tourism experience. Additionally, we discarded several constructs, and the relationships between them, when constructing the proposed conceptual model. Future research should explore some of these variables and relationships. For example, it would be useful to analyze what motivates tourists' to finally decide to visit this destination and see how these factors influence each of the image components (cognitive, affective and unique). It may be that tourists develop different perceptions about this type of destination's overall image based on their motivation (or lack thereof). Future studies should also explore how these socio-demographic characteristics (age, residence, work, level of studies, etc.) relate to people's willingness to visit such archeological destinations.

Possibly, a limitation may be the cognitive effect might not influence of the overall image, due to the existence of an indirect effect through the affective image.
Other avenues for future research include assessing how tourists' perceptions of a destination change before, during, and after the visit, as well as analyzing the role that local residents play in the formation of the different image components.

\section{DATA AVAILABILITY STATEMENT}

The raw data supporting the conclusions of this manuscript will be made available by the authors, without undue reservation, to any qualified researcher.

\section{ETHICS STATEMENT}

The studies involving human participants were reviewed and approved by Research Ethics Commission of the University of Castilla-La Mancha. The patients/participants provided their written informed consent to participate in this study.

\section{AUTHOR CONTRIBUTIONS}

All authors listed have made a substantial, direct and intellectual contribution to the work, and approved it for publication. 


\section{REFERENCES}

Ahmed, Z. U. (1991). The influence of the components of a state's tourist image on product positioning strategy. Tour. Manag. 12, 331-340. doi: 10.1016/02615177(91)90045-u

Alcañiz, E. B., Garcia, I. S., and Blas, S. S. (2009). The functional-psychological continuum in the cognitive image of a destination: a confirmatory analysis. Tour. Manag. 30, 715-723. doi: 10.1016/j.tourman.2008.10.020

Alcázar, C. H., and Sicilia, M. (2015). How web interactivity influences the image of a tourist destination. J. Urban Regeneration Renewal 8, 356-366.

Arias-Oliva, M., Pelegrín-Borondo, J., and Matías-Clavero, G. (2019). Variables influencing cryptocurrency use: a technology acceptance model in spain. Front. Psychol. 10, 1-13. doi: 10.3389/fpsyg.2019.00475

Baloglu, S. (1998). An empirical investigation of attitude theory for tourist destinations: a comparison of visitors and nonvisitors. J. Hospital. Tour. Res. 22, 211-224. doi: 10.1177/109634809802200301

Baloglu, S., and Brinberg, D. (1997). Affective images of tourism destinations. J. Travel Res. 35, 11-15. doi: 10.1177/004728759703500402

Baloglu, S., and McCleary, K. W. (1999). A model of destination image formation. Ann. Tour. Res. 26, 868-897. doi: 10.1016/s0160-7383(99)00030-4

Barclay, D. W., Higgins, C., and Thompson, R. (1995). The partial least squares approach to causal modeling: personal computer adoption and use as illustration. Technol. Stud. 2, 285-309.

Beerli, A., and Martín, J. D. (2004). Factors influencing destination image. Ann. Tour. Res. 31, 657-681. doi: 10.1016/j.annals.2004.01.010

Bigné, J. E., Sanchez, M. I., and Sanchez, J. (2001). Tourism image, evaluation variables and after purchase behaviour: inter-relationship. Tour. Manag. 22, 607-616. doi: 10.1016/s0261-5177(01)00035-8

Cai, L. A. (2002). Cooperative branding for rural destinations. Ann. Tour. Res. 29, 720-742. doi: 10.1016/s0160-7383(01)00080-9

Carballo, M. M., Araña, J. E., León, C. J., and Moreno-Gil, S. (2015). Economic valuation of tourism destination image. Tour. Econom. 21, 741-759. doi: $10.5367 /$ te.2014.0381

Carmines, E. G., and Zeller, R. A. (1979). Reliability and Validity Assessment. Thousand Oaks, CA: Sage publications.

Chaudhary, M. (2000). India's image as a tourist destination-a perspective of foreign tourists. Tour. Manag. 21, 293-297. doi: 10.1016/s0261-5177(99) 00053-9

Chen, C. C., Lai, Y. H. R., Petrick, J. F., and Lin, Y. H. (2016). Tourism between divided nations: an examination of stereotyping on destination image. Tour. Manag. 55, 25-36. doi: 10.1016/j.tourman.2016.01.012

Chen, C. F., and Tsai, D. (2007). How destination image and evaluative factors affect behavioral intentions? Tour. Manag. 28, 1115-1122. doi: 10.1016/j. tourman.2006.07.007

Cherifi, B., Smith, A., Maitland, R., and Stevenson, N. (2014). Destination images of non-visitors. Ann. Tour. Res. 49, 190-202. doi: 10.1016/j.annals.2014.09.008

Chi, C. G. Q., and Qu, H. (2008). Examining the structural relationships of destination image, tourist satisfaction and destination loyalty: an integrated approach. Tour. Manag. 29, 624-636. doi: 10.1016/j.tourman.2007.06.007

Chin W. W. (1998). The partial least squares approach to structural equation modeling. Modern Methods Bus. Res. 295, 295-336.

Chon, K. S. (1990). The role of destination image in tourism: a review and discussion. Tour. Rev. 45, 2-9. doi: 10.1108/eb058040

Coromina, L., and Camprubí, R. (2016). Analysis of tourism information sources using a Mokken Scale perspective. Tour. Manag. 56, 75-84. doi: 10.1016/j. tourman.2016.03.025

Crompton, J. L. (1979). An assessment of the image of mexico as a vacation destination and the, influence of geographical location upon that image. J. Travel Res. 17, 18-23. doi: 10.1177/004728757901700404

Cronbach, L. J. (1951). Coefficient alpha and the internal structure of tests. Psychometrika 16, 297-334. doi: 10.1007/bf02310555

Deng, Q., and Li, M. (2014). A model of event-destination image transfer. J. Travel Res. 53, 69-82. doi: 10.1177/0047287513491331

Dijkstra, T. K., and Henseler, J. (2015). Consistent partial least squares path modeling. MIS Q. Manag. Inf. Syst. Q. 39, 297-316.

Draper, J. (2016). An exploratory study of the differences in prior travel experience and tourist information sources. Tour. Hospital. Res. 16, 133-143. doi: 10.1177/ 1467358415600216
Echtner, C. M., and Ritchie, J. B. (1993). The measurement of destination image: an empirical assessment. J. Travel Res. 31, 3-13. doi: 10.1177/ 004728759303100402

Echtner, C. M., and Ritchie, J. R. (2003). The meaning and measurement of destination image [Reprint of original article published in v. 2, no. 2, 1991: 2-12.]. J. Tour. Stud. 14:37.

Echtner, C. M., and Ritchie, J. R. B. (1991). The meaning and measurement of destination image. J. Tour. Stud. 2, 2-12.

Ekinci, Y., and Hosany, S. (2006). Destination personality: an application of brand personality to tourism destinations. J. Travel Res. 45, 127-139. doi: 10.1177/ 0047287506291603

Elliot, S., and Papadopoulos, N. (2016). Of products and tourism destinations: an integrative, cross-national study of place image. J. Business Res. 69, 1157-1165. doi: 10.1016/j.jbusres.2015.08.031

Embacher, J., and Buttle, F. (1989). A repertory grid analysis of austria's image as a summer vacation destination. J. Travel Res. 27, 3-7. doi: 10.1177/ 004728758902700302

Fakeye, P. C., and Crompton, J. L. (1991). Image differences between prospective, first-time, and repeat visitors to the lower rio grande valley. J. Travel Res. 30, 10-16. doi: 10.1177/004728759103000202

Falk, R. F., and Miller, N. B. (1992). A Primer for Soft Modeling. Akron, OH: University of Akron Press.

Fornell, C., and Larcker, D. F. (1981). ). Evaluating structural equation models with unobservable variables and measurement error. J. Market. Res. 18, 39-50. doi: $10.1177 / 002224378101800104$

Fu, H., Ye, B. H., and Xiang, J. (2016). Reality TV, audience travel intentions, and destination image. Tour. Manag. 55, 37-48. doi: 10.1016/j.tourman.2016.01.009

Gallarza, M. G., Saura, I. G., and García, H. C. (2002). Destination image: towards a conceptual framework. Ann. Tour. Res. 29, 56-78.

Gartner, W. C. (1989). Tourism image: attribute measurement of state tourism products using multidimensional scaling techniques. J. Travel Res. 28, 16-20. doi: $10.1177 / 004728758902800205$

Gartner, W. C. (1994). Image formation process. J. Travel Tour. Market. 2, 191216.

Gartnerand, W. C., and Hunt, J. D. (1987). An analysis of state image change over a twelve-year period (1971-1983. J. Travel Res. 26, 15-19. doi: 10.1177/ 004728758702600204

Gold, A. H., Malhotra, A., and Segars, A. H. (2001). Knowledge management: an organizational capabilities perspective. J. Manag. Inf. Syst. 18, 185-214. doi: 10.1080/07421222.2001.11045669

Goodrich, J. N. (1978). The relationship between preferences for and perceptions of vacation destinations: application of a choice model. J. Travel Res. 17, 8-13. doi: 10.1177/004728757801700202

Gunn, C. A. (1972). Vacationscape: Designing Tourist Regions. Austin, TX: University of Texas.

Gunn, C. A. (1988). Vacationscape: Designing Tourist Regions. New York, NY: Van Nostrand Reinhold.

Gutiérrez, H. S. M., and del Bosque, I. R. (2010). Los factores estímulo y personales como determinantes de la formación de la imagen de marca de los destinos turísticos: un estudio aplicado a los turistas que visitan un destino vacacional. Cuadernos de Economía y Dirección de la Empresa 13, 37-63. doi: 10.1016/ s1138-5758(10)70009-8

Hair, J. F., Ringle, C. M., and Sarstedt, M. (2011). PLS-SEM: indeed a silver bullet. J. Market. Theory Pract. 19, 139-152. doi: 10.2753/mtp1069-6679190202

Henseler, J., Ringle, C. M., and Sarstedt, M. (2015). A new criterion for assessing discriminant validity in variance-based structural equation modeling. J. Acad. Market. Sci. 43, 115-135. doi: 10.1007/s11747-014-0403-8

Hosany, S., Ekinci, Y., and Uysal, M. (2007). Destination image and destination personality. Int. J. Cult. Tour. Hospital. Res. 1, 62-81.

Hsu, C. H., Wolfe, K., and Kang, S. K. (2004). Image assessment for a destination with limited comparative advantages. Tour. Manag. 25, 121-126. doi: 10.1016/ s0261-5177(03)00062-1

Hudson, S., Wang, Y., and Gil, S. M. (2011). The influence of a film on destination image and the desire to travel: a cross-cultural comparison. Int. J. Tour. Res. 13, 177-190.

Huete-Alcocer, N. (2017). A literature review of word of mouth and electronic word of mouth: implications for consumer behavior. Front. Psychol. 8:1256. doi: $10.3389 /$ fpsyg.2017.01256 
Hunt, J. D. (1971). Image: A Factor in Tourism. Ph.D. Dissertation, Fort Collins: Colorado State University.

Hunt, J. D. (1975). Image as a factor in tourism development. J. Travel Res. 13, 1-7. doi: $10.1177 / 004728757501300301$

Hunter, W. C. (2016). The social construction of tourism online destination image: a comparative semiotic analysis of the visual representation of Seoul. Tour. Manag. 54, 221-229. doi: 10.1016/j.tourman.2015.11.012

Jarvis, C. B., MacKenzie, S. B., and Podsakoff, P. M. (2003). A critical review of construct indicators and measurement model misspecification in marketing and consumer research. J. Consum. Res. 30, 199-218. doi: 10.1086/376806

Jeong, C., Holland, S., Jun, S. H., and Gibson, H. (2012). Enhancing destination image through travel website information. Int. J. Tour. Res. 14, 16-27. doi: $10.1002 /$ jtr. 827

Kim, H., and Richardson, S. L. (2003). Motion picture impacts on destination images. Ann. Tour. Res. 30, 216-237. doi: 10.1016/s0160-7383(02)00062-2

Kim, S. E., Lee, K. Y., Shin, S. I., and Yang, S. B. (2017). Effects of tourism information quality in social media on destination image formation: the case of sina weibo. Inf. Manag. 54, 687-702. doi: 10.1016/j.im.2017.02.009

Kim, S. S., and Morrsion, A. M. (2005). Change of images of south korea among foreign tourists after the 2002 FIFA World Cup. Tour. Manag. 26, 233-247. doi: 10.1016/j.tourman.2003.11.003

Kock, F., Josiassen, A., and Assaf, A. G. (2016). Advancing destination image: the destination content model. Ann. Tour. Res. 61, 28-44. doi: 10.1016/j.annals. 2016.07.003

Konecnik, M., and Gartner, W. C. (2007). Customer-Based Brand Equity for a Destination. Ann. Tour. Res. 24, 400-421. doi: 10.1016/j.annals.2006.10.005

Lai, K., and Li, X. (2016). Tourism destination image: conceptual problems and definitional solutions. J. Travel Res. 55, 1065-1080. doi: 10.1177/ 0047287515619693

Lai, K., and Li, Y. (2012). Core-periphery structure of destination image: concept, evidence and implication. Ann. Tour. Res. 39, 1359-1379. doi: 10.1016/j.annals. 2012.02.008

Li, X., Pan, B., Zhang, L., and Smith, W. W. (2009). The effect of online information search on image development: insights from a mixed-methods study. J. Travel Res. 48, 45-57. doi: 10.1177/0047287508328659

Lin, C. H., and Kuo, B. Z. L. (2018). The moderating effects of travel arrangement types on tourists' formation of taiwan's unique image. Tour. Manag. 66, 233243. doi: 10.1016/j.tourman.2017.12.001

Llodrà Riera, B. (2013). Gestión De la Imagen Del Destino En El Contexto Del Turismo 2.0: Recomendaciones Estratégicas Para Las Organizaciones de Marketing de Los Destinos (OMD). Ciudad Real: UCLM.

Llodrà-Riera, I., Martínez-Ruiz, M. P., Jiménez-Zarco, A. I., and Izquierdo-Yusta, A. (2015). A multidimensional analysis of the information sources construct and its relevance for destination image formation. Tour. Manage 48, 319-328. doi: 10.1016/j.tourman.2014.11.012

Maher, A. A., and Carter, L. L. (2011). The affective and cognitive components of country image: perceptions of american products in kuwait. Int. Market. Rev. 28, 559-580. doi: 10.1108/02651331111181411

Martín-Santana, J. D., Beerli-Palacio, A., and Nazzareno, P. A. (2017). Antecedents and consequences of destination image gap. Ann. Tour. Res. 62, 13-25. doi: 10.1016/j.annals.2016.11.001

Millet, O. F. (2010). La imagen De un Destino Turístico Como Herramienta de Marketing. Olga, PI: B-Olga Femenía Millet.

Molinillo, S., Liébana-Cabanillas, F., Anaya-Sánchez, R., and Buhalis, D. (2018). DMO online platforms: image and intention to visit. Tour. Manag. 65, 116-130. doi: 10.1016/j.tourman.2017.09.021

Moreno-Gil, S., Beerli-Palacio, A., and de León Ledesma, J. (2012). Entender la imagen de un destino turístico: factores que la integran y la influencia de las motivaciones. Criterio Libre 10, 115-142.

Nadeau, J., Heslop, L., O'Reilly, N., and Luk, P. (2008). Destination in a country image context. Ann. Tour. Res. 35, 84-106. doi: 10.1016/j.annals.2007. 06.012

Papadimitriou, D., Kaplanidou, K. K., and Apostolopoulou, A. (2015). Destination image components and word-of-mouth intentions in urban tourism: a multigroup approach. J. Hospital. Tour. Res. 5, 1-21.

Pike, S. (2002). Destination image analysis-a review of 142 papers from 1973 to 2000. Tour. Manag. 23, 541-549. doi: 10.1016/s0261-5177(02)00005-5
Pike, S. (2009). Destination brand positions of a competitive set of near-home destinations. Tour. Manag. 30, 857-866. doi: 10.1016/j.tourman.2008.12.007

Pike, S., and Ryan, C. (2004). Destination positioning analysis through a comparison of cognitive, affective, and conative perceptions. J. Travel Res. 42, 333-342. doi: 10.1177/0047287504263029

Prats, L., Camprubí, R., and Coromina, L. (2016). Examining the role of familiarity, information sources, length of stay and satisfaction to the image perception model. Eur. J. Tour. Res. 13:5.

Qu, H., Kim, L. H., and Im, H. H. (2011). A model of destination branding: integrating the concepts of the branding and destination image. Tour. Manag. 32, 465-476. doi: 10.1016/j.tourman.2010.03.014

Reilly, M. D. (1990). Free elicitation of descriptive adjectives for tourism image assessment. J. Travel Res. 28, 21-26. doi: 10.1177/004728759002800405

Rodríguez-Molina, M. A., Frías-Jamilena, D. M., and Castañeda-García, J. A. (2015). The contribution of website design to the generation of tourist destination image: the moderating effect of involvement. Tour. Manag. 47, 303-317. doi: 10.1016/j.tourman.2014.10.001

Royo-Vela, M. (2009). Rural-cultural excursion conceptualization: a local tourism marketing management model based on tourist destination image measurement. Tour. Manag. 30, 419-428. doi: 10.1016/j.tourman.2008. 07.013

Russell, J. A., and Pratt, G. (1980). A description of the affective quality attributed to environments. J. Pers. Soc. Psychol. 38:311. doi: 10.1037//0022-3514.38. 2.311

San Martín, H., and del Bosque, I. (2011). Un enfoque de gestión de la imagen de marca de los destinos turísticos basado en las características del turista. Revista de Análisis Turístico 9, 5-13.

San Martín, H., and del Bosque, I. A. R. (2008). Exploring the cognitiveaffective nature of destination image and the role of psychological factors in its formation. Tour. Manag. 29, 263-277. doi: 10.1016/j.tourman.2007. 03.012

Shmueli, G., Ray, S., Estrada, J. M. V., and Chatla, S. B. (2016). The elephant in the room: predictive performance of PLS models. J. Bus. Res. 69, 4552-4564. doi: 10.1016/j.jbusres.2016.03.049

Sirakaya, E., and Woodside, A. G. (2005). Building and testing theories of decision making by travellers. Tour. Manag. 26, 815-832. doi: 10.1016/j.tourman.2004. 05.004

Smith, W. W., Li, X. R., Pan, B., Witte, M., and Doherty, S. T. (2015). Tracking destination image across the trip experience with smartphone technology. Tour. Manag. 48, 113-122. doi: 10.1016/j.tourman.2014.04.010

Stepchenkova, S., and Li, X. R. (2012). Chinese outbound tourists' destination image of america: part II. J. Travel Res. 51, 687-703. doi: 10.1177/ 0047287512451137

Stepchenkova, S., and Mills, J. E. (2010). Destination image: a meta-analysis of 2000-2007 research. J. Hospital. Market. Manag. 19, 575-609. doi: 10.1080/ 19368623.2010.493071

Stepchenkova, S., and Morrison, A. M. (2008). Russia's destination image among American pleasure travelers: revisiting echtner and ritchie. Tour. Manag. 29, 548-560. doi: 10.1016/j.tourman.2007.06.003

Stern, E., and Krakover, S. (1993). The formation of a composite urban image. Geograph. Anal. 25, 130-146. doi: 10.1111/j.1538-4632.1993.tb00285.x

Stylidis, D., Shani, A., and Belhassen, Y. (2017). Testing an integrated destination image model across residents and tourists. Tour. Manag. 58, 184-195. doi: 10.1016/j.tourman.2016.10.014

Stylos, N., Vassiliadis, C. A., Bellou, V., and Andronikidis, A. (2016). Destination images, holistic images and personal normative beliefs: predictors of intention to revisit a destination. Tour. Manag. 53, 40-60. doi: 10.1016/j.tourman.2015. 09.006

Sun, M., Ryan, C., and Pan, S. (2015). Using chinese travel blogs to examine perceived destination image the case of new zealand. J. Travel Res. 54, 543-555. doi: 10.1177/0047287514522882

Sun, X., Chi, C. G. Q., and Xu, H. (2013). Developing destination loyalty: the case of Hainan Island. Ann. Tour. Res. 43, 547-577. doi: 10.1016/j.annals.2013.04.006

Tan, W. K., and Wu, C. E. (2016). An investigation of the relationships among destination familiarity, destination image and future visit intention. J. Destinat. Market. Manag. 5, 214-226. doi: 10.1016/j.jdmm.2015. 12.008 
Tang, L. R. (2014). The application of social psychology theories and concepts in hospitality and tourism studies: a review and research agenda. Int. J. Hospital. Manag. 36, 188-196. doi: 10.1016/j.ijhm.2013.09.003

Tasci, A. D., and Gartner, W. C. (2007). Destination image and its functional relationships. J. Travel Res. 45, 413-425. doi: 10.1177/004728750729 9569

Tasci, A. D., Gartner, W. C., and Cavusgil, S. T. (2007). Conceptualization and operationalization of destination image. J. Hospital. Tour. Res. 31, 194-223. doi: 10.1177/1096348006297290

Tseng, C., Wu, B., Morrison, A. M., Zhang, J., and Chen, Y. C. (2015). Travel blogs on china as a destination image formation agent: a qualitative analysis using Leximancer. Tour. Manag. 46, 347-358. doi: 10.1016/j.tourman.2014.07.012

Um, S., and Crompton, J. L. (1990). Attitude determinants in tourism destination choice. Ann. Tour. Res. 17, 432-448. doi: 10.1016/0160-7383(90)90008-f

Witter, B. S. (1985). Attitudes about a resort area: a comparison of tourists and local retailers. J. Travel Res. 24, 14-19. doi: 10.1177/004728758502400103

Woodside, A. G., and Lysonski, S. (1989). A general model of traveler destination choice. J. Travel Res. 27, 8-14. doi: 10.1177/004728758902700402
Yang, J., He, J., and Gu, Y. (2012). The implicit measurement of destination image: the application of implicit association tests. Tour. Manag. 33, 50-52. doi: 10.1016/j.tourman.2011.01.022

Zeng, B., and Gerritsen, R. (2014). What do we know about social media in tourism? a review. Tour. Manag. Persp. 10, 27-36. doi: 10.1016/j.tmp.2014. 01.001

Conflict of Interest: The authors declare that the research was conducted in the absence of any commercial or financial relationships that could be construed as a potential conflict of interest.

Copyright (C) 2019 Huete-Alcocer, Martinez-Ruiz, López-Ruiz and Izquiedo-Yusta. This is an open-access article distributed under the terms of the Creative Commons Attribution License (CC BY). The use, distribution or reproduction in other forums is permitted, provided the original author(s) and the copyright owner(s) are credited and that the original publication in this journal is cited, in accordance with accepted academic practice. No use, distribution or reproduction is permitted which does not comply with these terms. 